\title{
Far-off and close-up dry matter intake modulate indicators of immunometabolic adaptations to lactation in subcutaneous adipose tissue of pasture-based transition dairy cows
}

\author{
M. Vailati-Riboni, ${ }^{*}$ G. Farina, ${ }^{*} †$ F. Batistel, ${ }^{*}$ A. Heiser,ł M. D. Mitchell,§ M. A. Crookenden,\# C. G. Walker,\# \\ J. K. Kay, II S. Meier,II J. R. Roche, II and J. J. Loor ${ }^{* 1}$ \\ *Department of Animal Sciences and Division of Nutritional Sciences, University of Illinois, Urbana 61801 \\ †Dipartimento di Scienze Veterinarie per la salute, la produzione animale e la sicurezza alimentare (VESPA), Università di Milano, Milan, \\ Italy 20122 \\ $\ddagger$ AgResearch, Hopkirk Research Institute, Grasslands Research Centre, Palmerston North, New Zealand 4442 \\ §University of Queensland, Centre for Clinical Research, Royal Brisbane and Women's Hospital Campus, Herston, Queensland, Australia 4029 \\ \#DairyNZ Limited, c/o University of Auckland, 3A Symonds St., Auckland, New Zealand 1010 \\ IIDairyNZ Limited, Private Bag 3221, Hamilton, New Zealand 3240
}

\begin{abstract}
The common practice of increasing dietary energy density during the close-up dry period (last $\sim 3 \mathrm{wk}$ prepartum) has been recently associated with a higher incidence of metabolic disorders after calving. Despite these reports, over-feeding of metabolizable energy (ME) during the far-off, nonlactating period is a common management policy aimed at achieving optimum calving body condition score (BCS) in pasture-based systems, as cows are generally thinner than total mixed ration cows at the end of lactation. Our hypothesis was that both far-off and close-up overfeeding influence the peripartum adipose tissue changes associated with energy balance and inflammatory state. Sixty midlactation, grazing dairy cows of mixed age and breed were randomly allocated to 1 of 2 groups that were managed through late lactation to achieve a low and high BCS (approximately 4.25 and 5.0 on a 10-point scale) at dry-off. The low BCS cows were then overfed $\mathrm{ME}$ to ensure that they achieved the same BCS as the higher BCS group by calving. Within each rate of BCS gain treatment, cows were offered 65,90 , or $120 \%$ of their pre-calving $\mathrm{ME}$ requirements for 3 wk pre-calving in a $2 \times 3$ factorial arrangement of treatments (i.e., 10 cows/treatment). Subcutaneous adipose tissue was collected via biopsy at $-1,1$, and 4 wk relative to parturition. Quantitative PCR was used to measure mRNA and microRNA expression of targets related to adipogenesis and inflammation. Cows overfed in the far-off period had increased expression of miR-143 and miR-378 prepartum ( $-1 \mathrm{wk})$ indicating greater adipogenesis, consistent with their rapid gain in BCS
\end{abstract}

Received July 27, 2016.

Accepted November 13, 2016.

${ }^{1}$ Corresponding author: jloor@illinois.edu following dry-off. Furthermore, the lower postpartum expression of IL6, TNF, TLR4, TLR9, and miR-145, and a higher abundance of miR-99a indicated lower body fat mobilization in early lactation in the same group. In the close-up period, feeding either 65 or $120 \%$ of ME requirements caused changes in FASN, IL1B, IL6R, TLR9, and the microRNA miR-143, miR-155, and miR-378. Their respective expression patterns indicate a tentative negative-feedback mechanism in metabolically compromised, feed-restricted cows, and a possible immune-related stimulation of lipolysis in apparently static adipocytes in overfed cows. Data from cows fed $90 \%$ of ME requirements indicate the existence of a balance between lipolytic (inflammatory-related) and anti-lipolytic signals, to prime the mobilization machinery in light of imminent lactation. Overall, results indicate that far-off dry cow nutrition influences peripartum adipose tissue metabolism, with neither strategy negatively affecting the physiological adaptation to lactation. Furthermore, to ensure a favorable transition, cows should be subjected to a small feed restriction in the close-up period, irrespective of far-off nutritional management.

Key words: nutrition, transition period, inflammation, metabolism

\section{INTRODUCTION}

The BCS of a dairy cow is an assessment of the amount of body fat that it possesses. It is an important factor in dairy cattle management (Roche et al., 2009), due to its association with production and reproduction parameters and the chances for a successful lactation (Waltner et al., 1993; Roche et al., 2005; Pires et al., 2013; Randall et al., 2015). The progression of BCS in a TMR-based system during the lactation cycle (e.g., intercalving) is inversely related to the lactation curve 
(i.e., it declines to a nadir 40 to $100 \mathrm{~d}$ after calving as milk production peaks, before increasing again as milk production declines; Roche et al., 2009). However, in seasonal spring-calving cows grazing fresh pasture, a second period of loss in mid-lactation (Roche et al., 2007) leads to thinner cows at the end of lactation, compared with counterparts fed a TMR (Roche et al., 2007).

To avoid the detrimental physiological and metabolic effects of calving with a low BCS (Pires et al., 2013; Akbar et al., 2015), cows in pasture-based systems have to consume ME in excess of requirements during the far-off nonlactating period $(>4$ wk before calving) to achieve optimal calving BCS targets (Roche et al., 2009). However, Dann et al. (2006), working with TMR-fed cows, provided evidence that overfeeding in the far-off period might increase the risk of metabolic dysfunction during early lactation.

To further complicate peripartal nutritional management, cows are historically allowed ad libitum access to energy-dense feeds during the weeks before calving (Boutflour, 1928; i.e., during the so-called close-up dry period), thereby ensuring that cows do not lose condition pre-calving. Recent studies from different research groups have demonstrated, however, that this practice can lead to undesired outcomes including detrimental metabolic shifts such as increased postpartum blood FA concentration (Rukkwamsuk et al., 1999; Holtenius et al., 2003; Janovick et al., 2011; Ji et al., 2014; Khan et al., 2014) and poorer postpartum health indices (Dann et al., 2006; Soliman et al., 2007; Graugnard et al., 2013; Shahzad et al., 2014).

Adipose tissue plays an important role in the cow's adaptation to lactation and its metabolism is directly linked and responsive to DMI (McNamara, 1991, 1997). Furthermore, data from nonruminants underscore that it plays an active role in its self-regulation [e.g., through the production of adipokines (Adamczak and Wiecek, 2013; McGown et al., 2014; Musi and Guardado-Mendoza, 2014)]. Among its self-regulating features, adipose has the ability to generate a local inflammatory response, also (in human and mice models) through the recruitment and regulation of the innate immune system (Grant and Dixit, 2015), leading scientists to hypothesize a homeorhetic role of inflammation as a physiological adaptation to lactation (Mukesh et al., 2009; Farney et al., 2013; Vailati Riboni et al., 2015; Vailati Riboni et al., 2016).

A recent study (Arner and Kulyte, 2015) investigated the involvement of microRNA (miRNA) in fat cell formation (adipogenesis) and regulation of metabolic and endocrine functions; the results demonstrated how adipocyte metabolic pathways are not only controlled by the well-established changes in mRNA expression, but also that miRNA signaling through complex networks involving transcription factors plays an important role in the control of inflammation. Furthermore, miRNA expression patterns in humans have also been associated with levels of inflammatory molecules (e.g., cytokines) and the degree of immune cell infiltration (Kloting et al., 2009).

We previously demonstrated that prepartum BCS and level of nutrition in grazing cows can affect adipose tissue adaptation to lactation through complex immunometabolic pathways (Vailati-Riboni et al., 2016). Overfeeding optimally conditioned cows during close-up primed adipose tissue for accretion of lipid and caused a robust localized inflammatory response, which upon parturition may increase the probability for metabolic disorders. We hypothesized that far-off overfeeding could impair the adipose tissue adaptation to lactation, with further detrimental effects, or mitigation of these, when combined with close-up overfeeding, or feed-restriction, respectively. In the present study, gene and miRNA expression profiling was used to further understand the adipose responses to the physiological changes induced by the high metabolic demands of early lactation, and their interaction with far-off and close-up nutritional strategies.

\section{MATERIALS AND METHODS}

\section{Animal Management}

Complete details of the experimental design are reported elsewhere (Roche et al., 2016). Briefly, a group of 150 mid-lactation dairy cows (that passed a veterinary clinical examination, which included a full pathology health panel) of mixed age and breed (Holstein-Friesian, Jersey, Holstein-Friesian $\times$ Jersey) were allocated randomly to one of 2 treatment groups (75 cows per group) $18 \mathrm{wk}$ before planned start of calving, and managed through late lactation to achieve a high and low BCS (approximately 4.75 and 4.25, on a 10-point scale, where 1 is emaciated and 10 is obese; Roche et al., 2004). Consequently, to reach optimal calving BCS (5.00, Roche et al., 2004), the high BCS group had $<0.25$ BCS units to gain during the 5 -wk far-off period (SlowBCS gain), whereas the low BCS cows were overfed to ensure a gain of 0.75 to $1.0 \mathrm{BCS}$ units in the same period (FastBCS gain). From approximately 3 wk before calving, cows within each BCS gain group were randomly assigned in a $2 \times 3$ factorial arrangement of treatments to 1 of 3 feeding level categories: 65,90 , and $120 \%$ of estimated ME requirements (Feed65, Feed90, and Feed120, respectively). Although cow allocation to treatment was random, groups were assessed to ensure they were balanced for 
age, breed, BCS at the time of enrolment, and expected calving date. For the current study, only a subset of 60 animals (10 cows per group) with adipose tissue biopsy samples available was considered.

\section{RNA Extraction and Quantitative PCR}

Complete details of these procedures are included in the Supplemental Material (https://doi.org/10.3168/ jds.2016-11790). Briefly, subcutaneous adipose tissue was collected posterior to the shoulder blade and approximately $10 \mathrm{~cm}$ down the withers during wk $-1,1$, and 4 relative to parturition as described previously (Grala et al., 2013). Average sampling date (mean \pm $\mathrm{SD})$ for wk $-1,1$, and 4 was $-10.4 \pm 2.4,6.4 \pm 0.9$, and $27.4 \pm 0.9 \mathrm{~d}$ relative to parturition, respectively. The RNA samples were extracted from the frozen tissue and used for cDNA synthesis using established protocols in our laboratory (Vailati Riboni et al., 2016). The Quanta qScript microRNA cDNA Synthesis Kit (Quanta BioSciences Inc., Gaithersburg, MD) was used for miRNA following the manufacturer's protocols. The quantitative PCR (qPCR) performed was SYBR Green-based, using a 7-point standard curve obtained from a diluted cDNA pool of all samples. Genes selected for transcript profiling are associated with fatty acid metabolism: fatty acid synthase $(F A S N)$ and peroxisome proliferator-activated receptor gamma (PPARG); adipokines: adiponectin $(A D I P O Q)$; and inflammation: chemokine (C-C motif) ligand 2 (CCL2), chemokine (C-C motif) ligand 5 (CCL5), haptoglobin (HP), IL-1 $\beta$ (IL1B), IL-6 (IL6), IL-6 receptor (IL6R), retinoid X receptor a $(R X R A)$, serum amyloid A3 (SAA3), tolllike receptor 4 (TLR4), toll-like receptor 9 (TLR 9$)$, and tumor necrosis factor $\alpha(T N F)$. The miRNA selected for expression profiling are associated with immune cell infiltration (miR-26b, miR-126, miR-132, miR-155, miR-193b), inflammation and lipolysis (miR-99a, miR145, miR-221), and positive regulation of adipogenesis (miR-103, miR-143, miR-378). The specific function of each target miRNA is reported in Table 1, including the model system in which the function was assessed. Primer sequences and qPCR performances are reported in Supplemental Tables S1, S2, S3, and S4 (https://doi. org/10.3168/jds.2016-11790).

\section{Blood Sampling and Analysis}

Blood was sampled by coccygeal venipuncture using evacuated blood tubes containing lithium heparin anticoagulant. Samples were placed immediately on ice and centrifuged within $30 \mathrm{~min}$ at 1,500 $\times g$ for $12 \mathrm{~min}$ at $4^{\circ} \mathrm{C}$. Following centrifugation, aspirated plasma was stored at $-20^{\circ} \mathrm{C}$ until assayed.

Blood free fatty acids (FA) and BHB were assayed using colorimetric techniques at $37^{\circ} \mathrm{C}$ with a Hitachi Modular P800 analyzer (Roche Diagnostics, Indianapolis, IN). Plasma FA concentration $(\mathrm{mmol} / \mathrm{L})$ was measured using the Wako Chemicals (Osaka, Japan) kit NEFA HR2 measuring oxidative condensation of 3 -methyl-N-ethyl-N- $\beta$ hydroxyethyl aniline with 4 -aminoantipyrine, whereas plasma BHB (mmol/L) concentration was assessed using Roche reagent kits measuring the reduction of NAD to NADH during oxidation of d-3-hydroxybutyrate to acetoacetate. Cholesterol was measured using a commercially available fluorimetric kit (Cayman Chemical Company, Ann Arbor, MI).

\section{Statistical Analysis}

After normalization with the geometric mean of the internal control genes, qPCR data (mRNA and miRNA) were $\log _{2}$ transformed before statistical analysis to obtain a normal distribution. Statistical analysis was performed with SAS (version 9.3, SAS Institute Inc., Cary, NC). Data were subjected to ANOVA and analyzed using repeated measures ANOVA with PROC MIXED. The statistical model included time $(\mathbf{T} ;-1,1$, and 4 wk postpartum), far-off management (FO; slow and fast), close-up feeding (CU, 65, 90, and 120\%), and their interactions $(\mathrm{FO} \times \mathrm{T}, \mathrm{CU} \times \mathrm{T}$, and $\mathrm{FO} \times \mathrm{CU} \times$ T) as fixed effects. Cow, nested within treatment, was the random effect. The Kenward-Roger statement was used for computing the denominator degrees of freedom, whereas spatial power was used as the covariance structure. Data were considered significant at a $P \leq 0.05$ using the PDIFF statement in SAS. For ease of interpretation, expression data reported in Tables 2 through 5 are the $\log _{2}$ back-transformed least squares means that resulted from the statistical analysis. Standard errors were also adequately back-transformed. The 3-way interaction least squares means are not reported in the tables and can be found in Supplemental Tables S5, S6, and S7 (https://doi.org/10.3168/jds.2016-11790).

\section{RESULTS}

\section{Gene Expression}

Infiltration of Immune Cells. No effect was found of feeding strategy or time on CCL5 (T, FO, CU, and interactions, $P>0.05)$, whereas $C C L 2$ expression was affected by CU $(P<0.05$; Table 2$)$, T $(P<0.05)$, and their interaction $(\mathrm{CU} \times \mathrm{T}, P<0.05$; Table 3$)$. Expression of $C C L 2$ was greater prepartum in Feed120 cows, 
compared with Feed65 and Feed90. Early postpartum (1 wk), both Feed120 and Feed90 cows had a greater CCL2 expression than Feed65 cows, but no effect was detected of treatment later on (4 wk). This outcome was due to the different progression in time; compared with prepartum, Feed90 cows experienced a strong upregulation $(P<0.05)$ of $C C L 2$ at both 1 and 4 wk postpartum time points, whereas the same increase $(P<$ $0.05)$ in Feed65 cows did not materialize until the $4 \mathrm{wk}$ postpartum. Expression of CCL2 in Feed120 cows did not change $(P>0.05)$ during the peripartum period.

Inflammation and Lipolysis-Related Proteins and Receptors. Parturition affected expression of $H P$ and $S A A 3(\mathrm{~T}, P<0.05)$ due to an upregulation early postpartum independent from experimental groups $(P<0.05$; Table 3$)$. The IL6, TLR4, and TLR9 were affected by FO $(P<0.05)$, as SlowBCS cows had a greater expression $(P<0.05)$ compared with FastBCS cows (Table 2). For TLR 4, however, a FO $\times \mathrm{T}$ interaction $(P=0.05)$ indicated that this effect was only present prepartum (Table 3). Close-up feeding also affected expression of IL1B (CU, P<0.05),IL6R, TLR4, TLR9 $(\mathrm{CU}, \mathrm{CU} \times \mathrm{T}, P<0.05), I L 6$, and TNF $(\mathrm{CU} \times \mathrm{T}, P$ $<0.05$; Tables 2 and 3). Compared with the other 2 groups, overfed cows (Feed120) had lower expression $(P<0.05)$ of IL1B, TLR9, and IL6R. However, when time is taken into consideration, this effect was only present for IL6R and TLR9 postpartum (wk 1 and 4), as prepartum (wk -1) both Feed90 and Feed120 had a lower expression $(P<0.05)$ compared with Feed65.

Feed90 cows had increased the expression $(P<0.05)$ of $I L 1 B$ over the entire period, IL 6 early postpartum (wk 1), TLR 4 overall postpartum (wk 1 and 4), and TNF late postpartum (wk 4).

$\mathrm{An}$ interaction between $\mathrm{FO}$ and $\mathrm{CU}$ was detected for $I L 1 B$ and TNF $(\mathrm{FO} \times \mathrm{CU}, P<0.01$; Table 3$)$. Overfeeding SlowBCS or feed-restricting FastBCS cows led to lower $(P<0.05)$ expression of these genes. Furthermore, TNF expression was also significant for the 3 -way interaction $(\mathrm{FO} \times \mathrm{CU} \times \mathrm{T}, P<0.05)$ (Supplemental Figure S1; https://doi.org/10.3168/jds.2016-11790). In SlowBCS cows, overfeeding decreased TNF expression

Table 1. Details and functions of the microRNA (miRNA) targets analyzed in the current study, adapted from Vailati Riboni et al. (2016), Moisá et al. (2016), and Arner and Kulyte (2015)

\begin{tabular}{|c|c|c|c|}
\hline miRNA & Function, expression pattern, or both & $\begin{array}{l}\text { Model } \\
\text { system }^{1}\end{array}$ & Reference \\
\hline $\begin{array}{l}\text { Infiltration of immune cells } \\
\text { miR-26b }\end{array}$ & $\begin{array}{l}\text { Expression is associated with the number } \\
\text { of macrophages infiltrating the fat depot } \\
\text { Affected by levels of circulating TNF, } \\
\text { leptin, and resistin }\end{array}$ & $\mathrm{Hu}$ & Kloting et al., 2009; Xu et al., 2013 \\
\hline $\operatorname{miR}-126$ & Directly inhibits $C C L 2$ expression & $\mathrm{Hu}$ & Kloting et al., 2009: Arner et al., 2012 \\
\hline $\operatorname{miR}-155$ & $\begin{array}{l}\text { Expression levels are associated with the } \\
\text { number of macrophages infiltrating fat } \\
\text { depots }\end{array}$ & $\mathrm{Hu}$ & Kloting et al., 2009 \\
\hline $\begin{array}{l}\text { Inflammation and lipolysis } \\
\text { miR-99a }\end{array}$ & $\begin{array}{l}\text { Negative correlation with secretion of } \\
\text { IL- } 6 \text { and level of free fatty acids }\end{array}$ & $\mathrm{Hu}$ & Kloting et al., 2009 \\
\hline $\operatorname{miR}-145$ & $\begin{array}{l}\text { Affects secretion of } \mathrm{TNF} \alpha \text {, regulating } \\
\text { lipolysis }\end{array}$ & $\mathrm{Hu}$ & Lorente-Cebrian et al., 2014 \\
\hline $\operatorname{miR}-221$ & $\begin{array}{l}\text { Lower expression is associated with high } \\
\text { levels of TNF } \alpha\end{array}$ & $\mathrm{Hu}$ & Chou et al., 2013 \\
\hline $\begin{array}{l}\text { Proadipogenic } \\
\text { miR-103 }\end{array}$ & $\begin{array}{l}\text { Regulates expression of } P P A R G, P A N K 1 \text {, } \\
C A V 1, F A S N, A D I P O Q \text {, and FABP4 }\end{array}$ & Bo, Ma, Mo & $\begin{array}{l}\text { Romao et al., 2011; Trajkovski et al., 2011, } \\
\text { John et al., 2012, Romao et al., } 2014\end{array}$ \\
\hline $\operatorname{miR}-143$ & $\begin{array}{l}\text { Regulates expression of } E R K 5, S L C 2 A 4 \text {, } \\
\text { TFAP2A, LIPE, PPARG,CEBPA, and } \\
\text { FABP4 }\end{array}$ & $\begin{array}{l}\text { Bo, } \mathrm{Hu}, \mathrm{Ma} \\
\text { Mo }\end{array}$ & $\begin{array}{l}\text { Esau et al., 2004; Kajimoto et al., 2006, Xie } \\
\text { et al., 2009; Jin et al., 2010; Li et al., 2011; } \\
\text { Romao et al., } 2011\end{array}$ \\
\hline $\operatorname{miR}-378$ & $\begin{array}{l}\text { Targets } P P A R G \text { expression through the } \\
\text { MAPK1 pathway }\end{array}$ & B, Mo & $\begin{array}{l}\text { Gerin et al., 2010; Jin et al., 2010; John et al., } \\
\text { 2012; Sacco and Adeli, 2012; Liu et al., } 2015\end{array}$ \\
\hline
\end{tabular}

${ }^{1} \mathrm{Bo}=$ bovine (Bos taurus); $\mathrm{Hu}=$ human; $\mathrm{Ma}=$ mammalian; $\mathrm{Mo}=$ mouse. 
VAILATI-RIBONI ET AL.

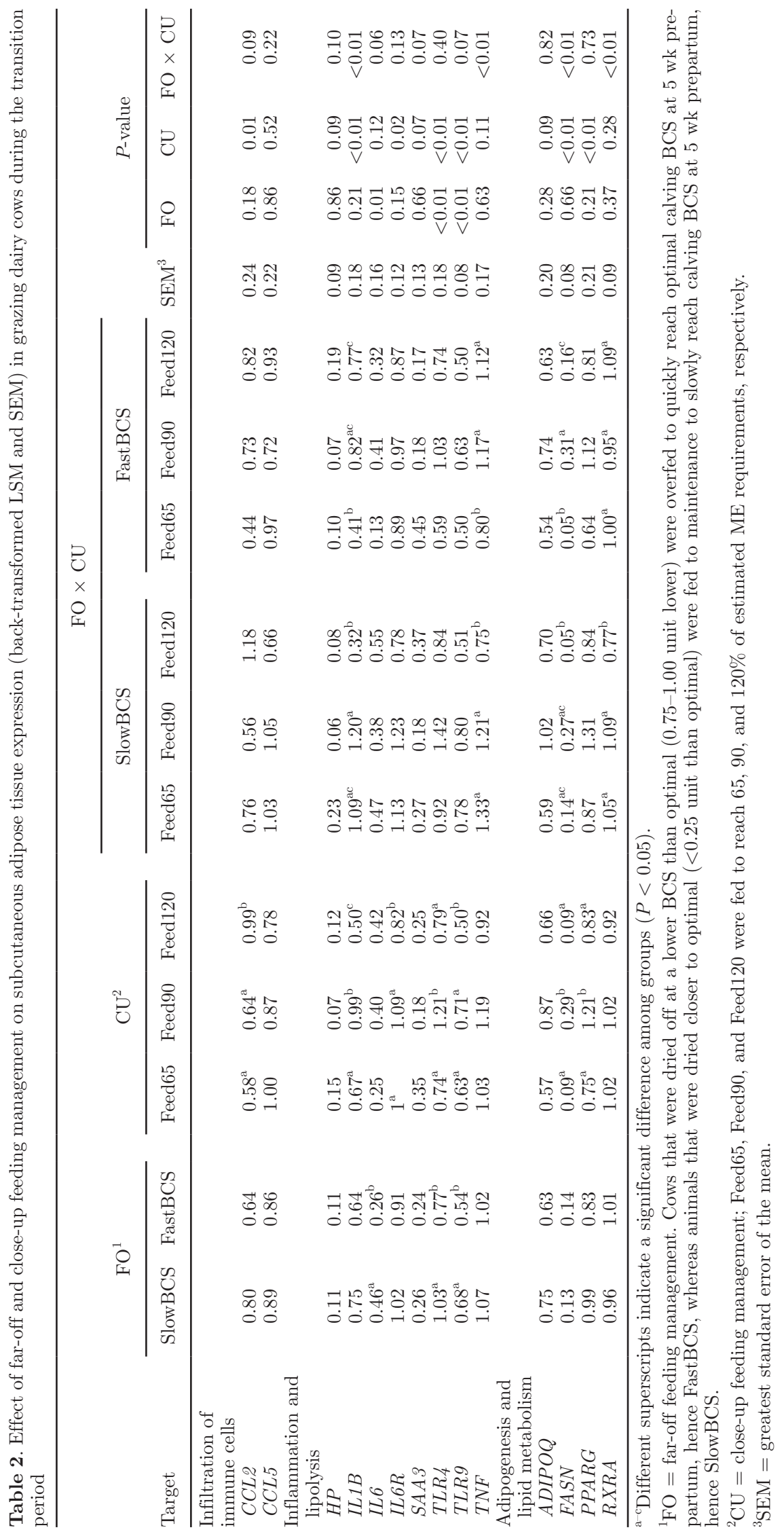


at wk 4 postpartum; however, in FastBCS cows, feeding $90 \%$ of requirements increased expression at wk 1 postpartum (Supplemental Figure S1; https://doi. org/10.3168/jds.2016-11790).

Adipogenesis and Lipid Metabolism. Far-off management did not affect the expression of any of the genes in this category (FO, $P>0.05$ ); however, $\mathrm{CU}$ affected the expression of FASN (CU, CU $\times$ T, $P<$ $0.05), P P A R G(\mathrm{CU}, \mathrm{CU} \times \mathrm{T}, P<0.05)$, and $A D I P O Q$ $(\mathrm{CU} \times \mathrm{T}, P=0.05)$, as feeding cows $90 \%$ of ME requirements during this period increased $(P<0.05)$ the expression of these genes prepartum $(-1 \mathrm{wk})$ relative to feeding 60 or $120 \%$ of requirements (Tables 2 and 3 ). A carry-over effect was also detected for PPARG and $A D I P O Q$, as their expression was still upregulated $1 \mathrm{wk}$ postpartum in Feed90 cows. Furthermore, parturition had a strong effect $(\mathrm{T}, P<0.01)$, causing a significant downregulation $(P<0.05)$ postpartum of all 4 genes (Table 3).

An interaction between $\mathrm{FO}$ and $\mathrm{CU}$ was detected for FASN and RXRA (FO $\times \mathrm{CU}, P<0.01)$. For both genes, the overall expression decreased $(P<0.05)$ when SlowBCS cows were overfed (i.e., Feed120), whereas the same response $(P<0.05)$ was also detected for FASN when the FastBCS group was severely restricted (i.e., Feed65).

\section{MicroRNA Expression}

Inflammation and Lipolysis-Related. Overfeeding cows during the far-off period (FastBCS) led to greater $(P<0.05)$ expression of miR-99a, mainly prepartum $(\mathrm{FO} \times \mathrm{T}, P<0.05)$, whereas it decreased $(P<$ $0.05)$ expression of miR-145 over the entire transition period (FO, $P<0.05$; Tables 4 and 5). Expression of miR-221 was affected by $\mathrm{T}(P<0.05)$ and $\mathrm{CU}(P<$ $0.05)$, with greater $(P<0.05)$ overall expression postpartum and a greater $(P<0.05)$ expression in cows overfed close to parturition (Feed120).

All 3 miRNA (miR-99a, miR-145, and miR-221) had a significant 2-way interaction between far-off management and close-up feeding $(\mathrm{FO} \times \mathrm{CU}, P<0.05)$, with greater expression in either SlowBCS-Feed120 or FastBCS-Feed65 cows (Table 4).

Adipose Infiltration of Immune Cells. Time had an opposite effect on expression of miR-155 and miR193b (T, $P<0.05$ ), with an increase in expression $(P<0.05)$ postpartum for the former, and a decrease $(P<0.05)$ in expression after parturition with the latter (Table 5).

Far-off management had an overall effect on miR-132 $($ FO, $P<0.05)$ and a prepartum effect on miR-126 and miR-155 (FO $\times$ T, $P<0.05$; Tables 4 and 5). Similar to prepartal expression of miR-155, the expression of
miR-132 was greater $(P<0.05)$ in SlowBCS cows, whereas in the same group, expression was lower $(P<$ 0.05) prepartum for miR-126.

Close-up feeding had a significant effect on miRNA involved in immune cell infiltration $(\mathrm{CU}, P<0.05$; miR-26b, miR-132, and miR-155; $\mathrm{CU} \times \mathrm{T}, P<0.05$; miR-126 and miR-193b). The Feed120 cows had the greatest overall $(P<0.05)$ expression of miR-132 and miR155, with the lowest $(P<0.05)$ expression of miR26b. The miR-126 and miR-193b were only affected postpartum, with Feed90 cows having the greatest $(P$ $<0.05$ ) expression of miR-126 (wk 1) and the lowest ( $P$ $<0.05$ ) expression of miR-193b (wk 1 and 4).

$\mathrm{An}$ interaction between $\mathrm{FO}$ and $\mathrm{CU}$ was detected for miR-126 and miR-155 (FO $\times$ CU, $P<0.05)$. In both cases, the greatest $(P<0.05)$ expression was detected in overfed (Feed120) SlowBCS and feed-restricted (Feed65) FastBCS cows.

Proadipogenic miRNA. Far-off management affected expression of miR-143 and miR-378, with greater $(P<0.05)$ prepartal expression in FastBCS compared with SlowBCS cows $(\mathrm{FO} \times \mathrm{T}, P<0.05)$. The same miRNA were also affected by close-up feeding $(\mathrm{CU} \times \mathrm{T}$, $P=0.01$; Table 5). Expression of miR-143 was greater $(P<0.05)$ in Feed65 and Feed90 prepartum and early postpartum (wk 1), respectively. No differences $(P>$ $0.05)$ were detected at $4 \mathrm{wk}$ postpartum. Expression of miR-378 was greater $(P<0.05)$ in Feed90 cows prepartum and in Feed120 late postpartum (4 wk). No differences $(P>0.05)$ were detected early postpartum (wk 1) for this miRNA. Expression of miR-103 also was affected by $\mathrm{CU}(P<0.05)$, with increased expression in Feed90 compared with the other groups (Table 4$)$. This was mainly due to an interaction with far-off management, such that SlowBCS cows experienced no change when fed differently in the close-up period, whereas FastBCS cows had the highest expression of miR-103 when feed-restricted (Feed65), and lowest in the Feed90 group $(\mathrm{FO} \times \mathrm{CU}, P<0.05)$.

\section{Blood Metabolites}

Fatty acids were the only metabolite affected by FO $(P<0.05)$, with greater concentrations in SlowBCS cows (Table 6). Close-up feeding level also affected their concentration ( $\mathrm{CU}, \mathrm{CU} \times \mathrm{T}, P<0.05)$, mainly due to prepartum concentrations being inversely correlated with feeding level (Feed65 > Feed90 > Feed120). Similarly, BHB and cholesterol concentrations were greater $(\mathrm{CU} \times \mathrm{T}, P<0.05)$ prepartum in underfed than overfed cows $(\mathrm{CU} \times \mathrm{T}, P<0.05)$. However, for cholesterol, its concentrations changed at wk 4 postpartum, with higher $(P<0.05)$ concentrations in Feed90 compared with other feeding groups. 
VAILATI-RIBONI ET AL.

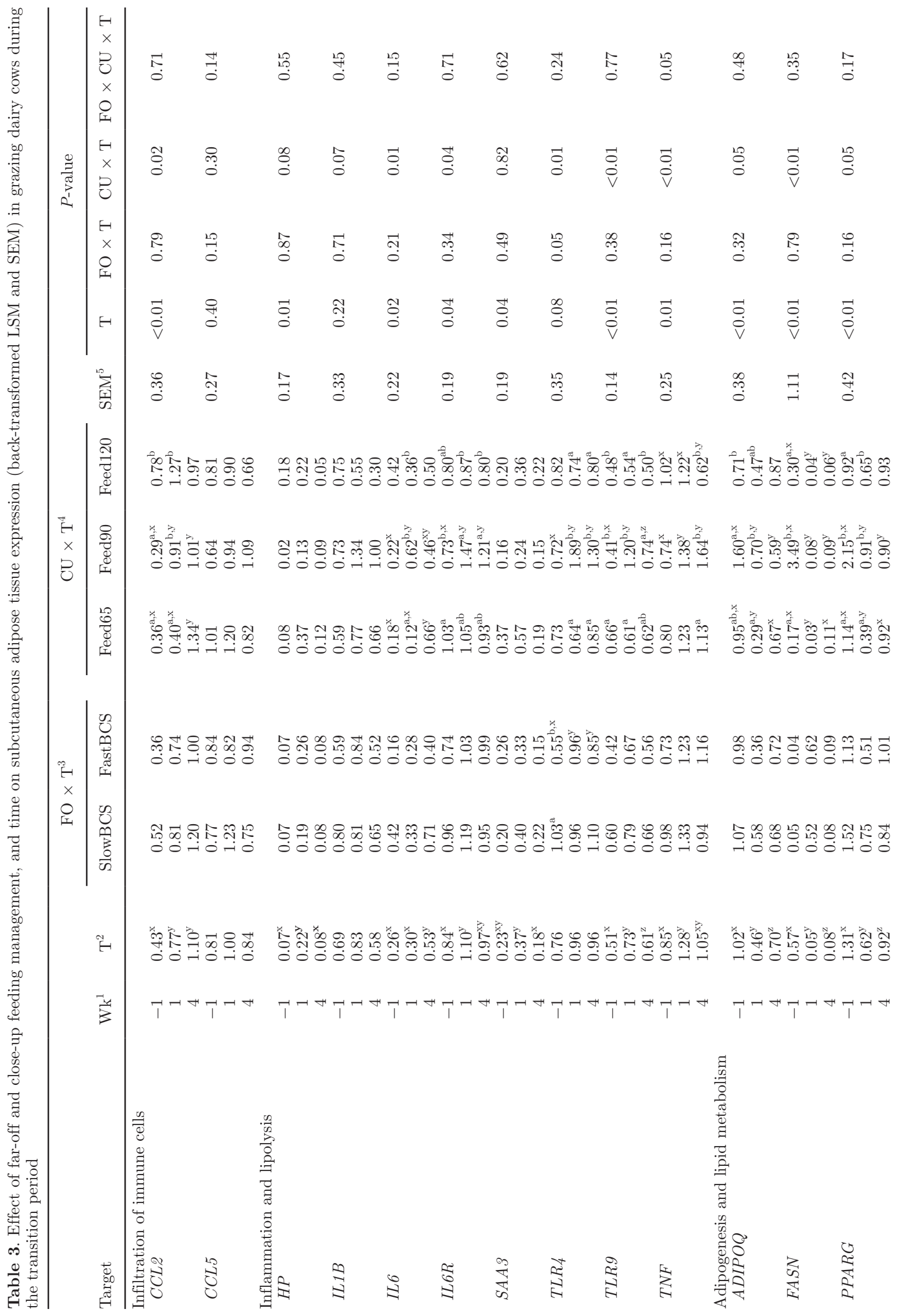


Time affected blood concentrations of fatty acids, BHB, and cholesterol (T, $P<0.05$; Table 7). Fatty acid and BHB concentrations were greatest $(P<0.05)$ early postpartum (wk 1). Compared with prepartum concentrations, postpartum concentrations of cholesterol decreased $(P<0.05)$.

\section{DISCUSSION}

The combination of mRNA and miRNA profiling has been used previously to understand the molecular selfregulatory mechanism within the adipose depot during the transition period in dairy cows in the context of the relationship between dry period BCS and close-up feeding (Vailati Riboni et al., 2016). Our present work demonstrates that part of the variation caused by BCS could be attributed to the nutritional strategies used to allow cows to reach optimal adiposity at calving. Furthermore, the level of nutrition from close-up to calving could interact with far-off management.

In our previous experiment (Vailati Riboni et al., 2016), we speculated that the infiltration of immune cells in the cow adipose tissue around parturition is part of the regulatory mechanisms in adipose tissue. Despite differences in cellularity, adipokine production, and gene expression (e.g., abundance), and cell systems between omental and subcutaneous adipose tissue (Dodson et al., 2014), the latter was used in the present study to allow for multiple sampling across time on the same animal, which is central for the mechanistic understanding during the transition period.

Recently, Akter et al. (2012) concluded that the extent of fatness in early lactating dairy cows may not be high enough to stimulate significant infiltration of phagocytic cells and, therefore, these immune cells may have no major role in the immunologic and metabolic adaptations during early lactation. This was supported by the analysis of chemoattractant molecule CCL2 mRNA and protein distribution in the adipose tissue of the same animals (Haussler et al., 2015). However, both studies, based on the experiment of von Soosten et al. (2011), used Holstein heifers rather than multiparous mature cows as a model. As heifers are still growing and developing during their first lactation, adipose mobilization is generally less prominent than mature cows (e.g., lower fatty acids and BHB). The authors justified the choice of heifers as a way to avoid the influence of previous lactations on adaptations within the adipose tissue. However, the first lactation might be of substantial importance to develop the adaptive mechanisms that will help the animal support the greater production performance of the subsequent lactations.

When taking into consideration the work of Contreras et al. (2015) using multiparous cows with displaced 
VAILATI-RIBONI ET AL.

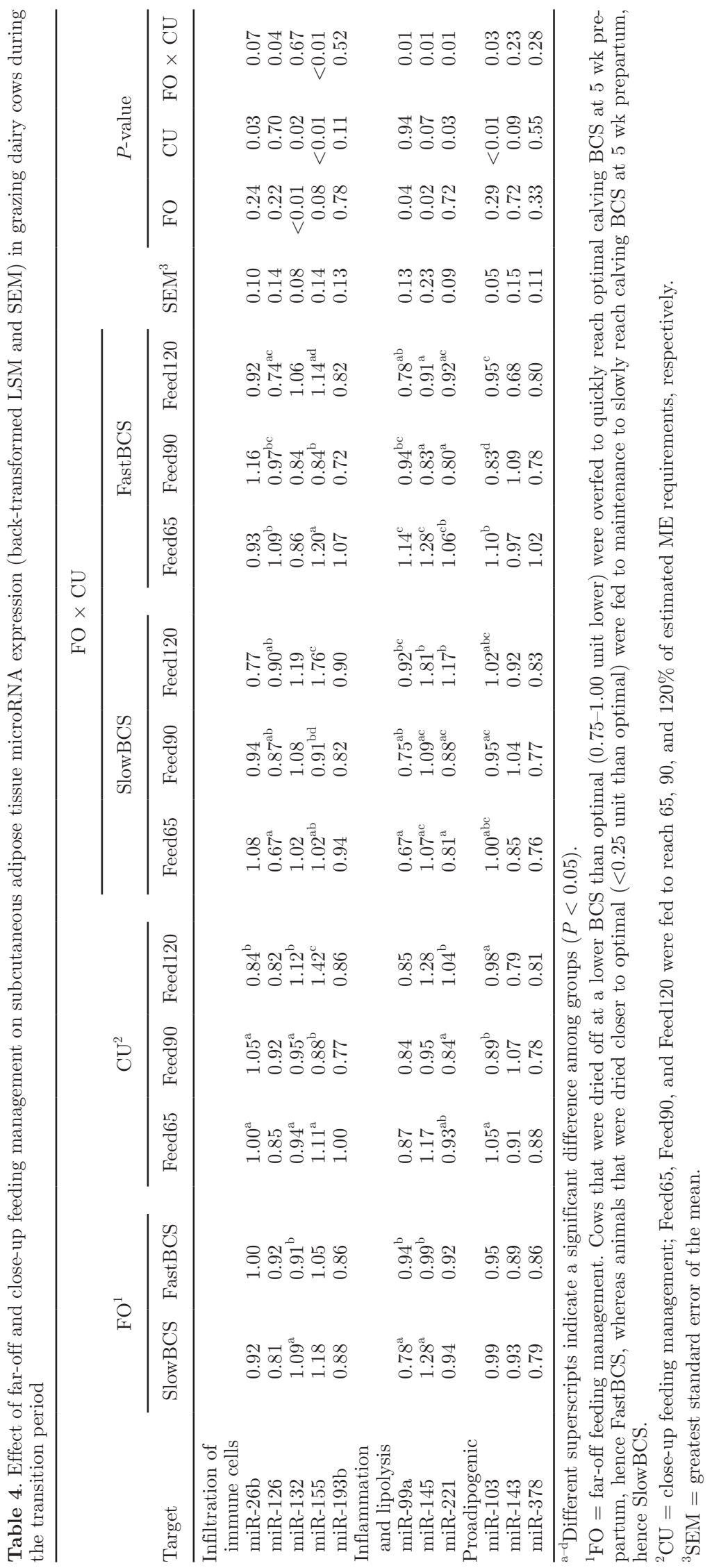


DRY COW NUTRITION AND ADIPOSE TISSUE IMMUNOMETABOLISM

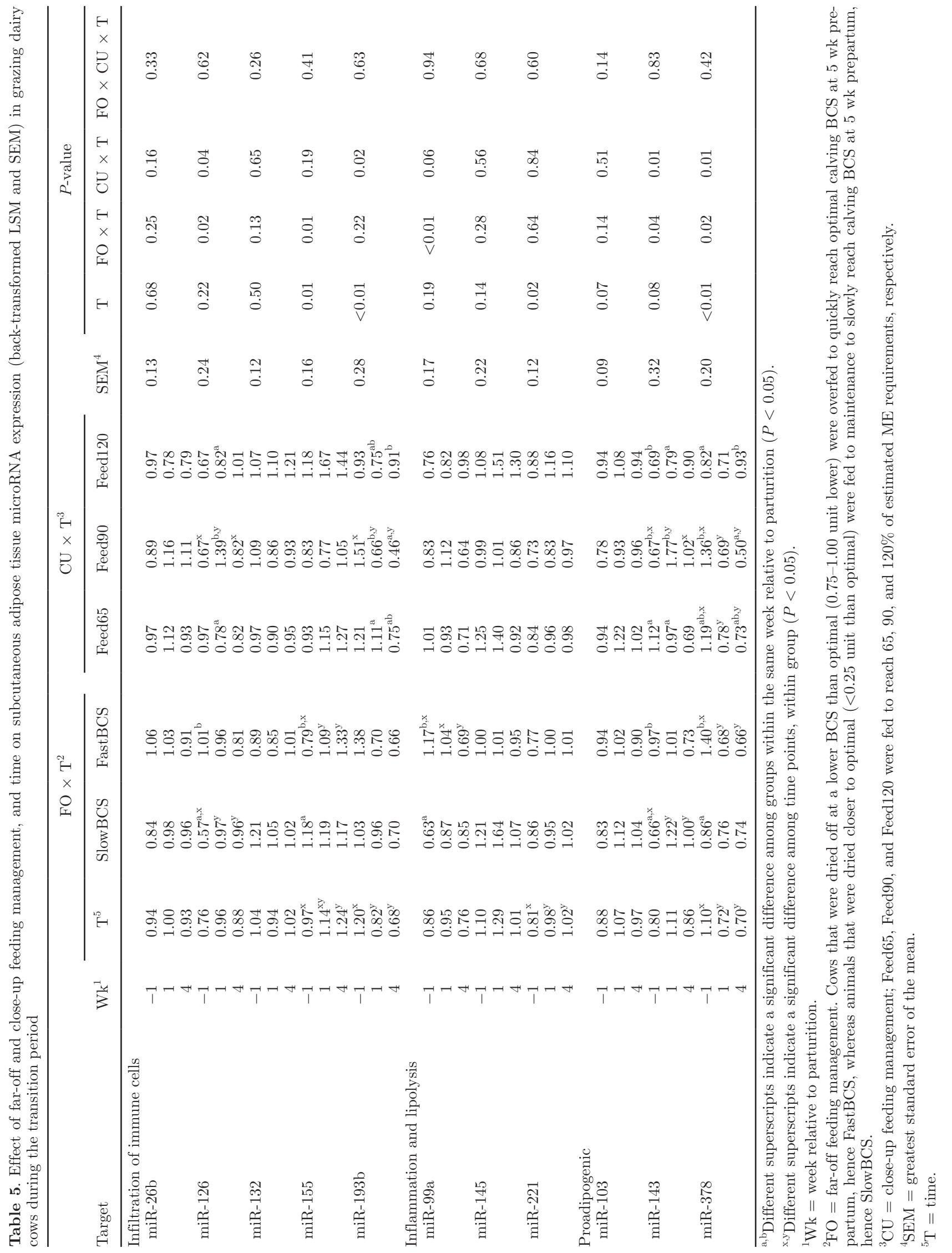



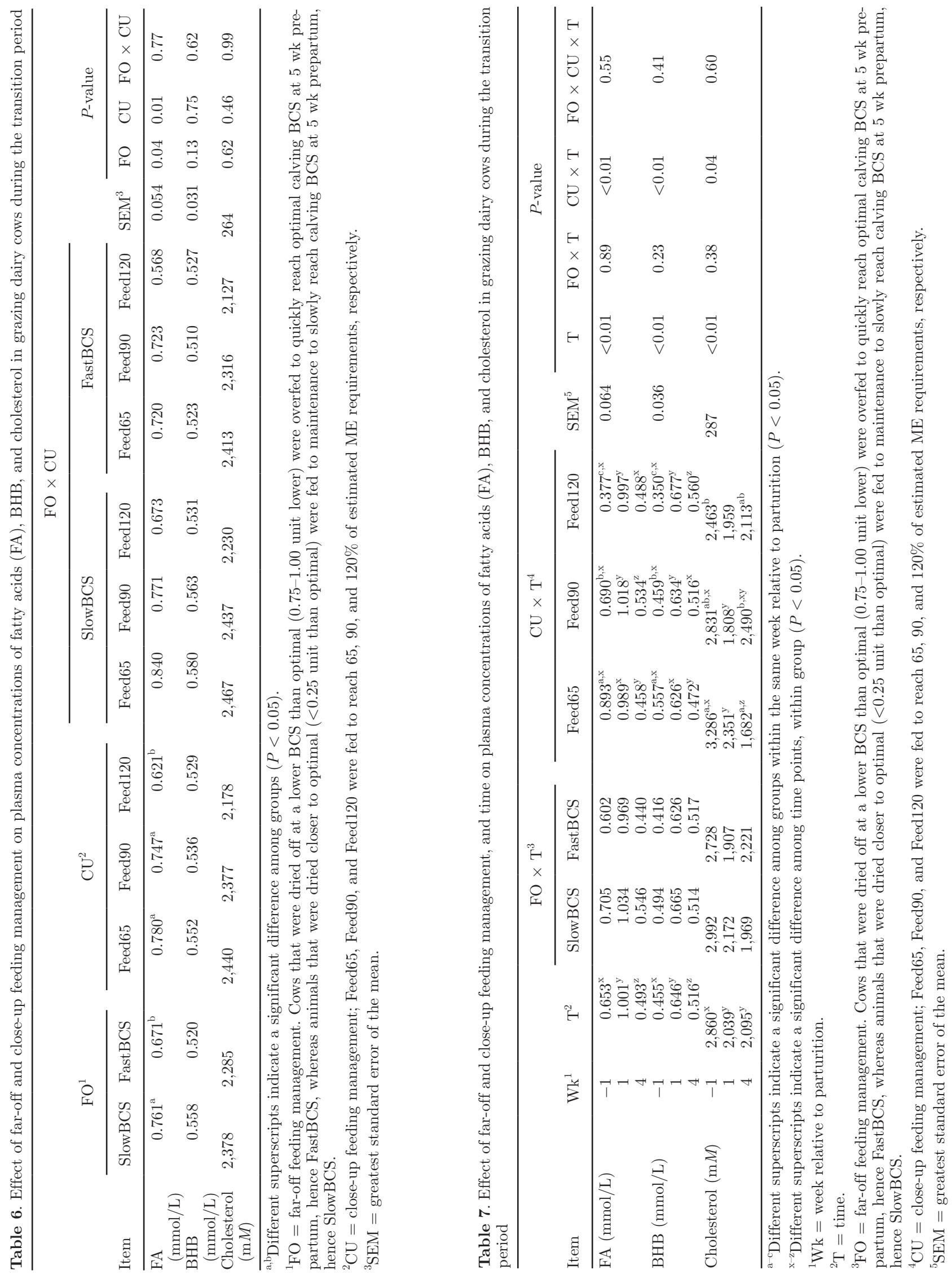
abomasum in early lactation compared with nonlactating healthy cows, and using flow cytometry rather than immunostaining, a degree of immune infiltration was detected not only in both subcutaneous and omental fat, but also in healthy cows with no difference in cell markers (CD14, CD172a, CD11c, CD163, CD3) between depots. When interpreting the immunostaining results, the authors described the macrophage counts in subcutaneous adipose tissue of healthy cows as "sparse and randomly localized" in relation to the adipocyte numbers. Because those were multiparous nonlactating and nongestating dairy cows in an anabolic state, the possibility that healthy cows might experience a physiologically functional degree of immune cell infiltration during the catabolic peripartal period cannot be excluded.

We recognize the importance of direct measurements of adipose tissue immune cell infiltration (i.e., flow cytometry, immunohistochemistry, or both), but despite their absence in the present study, miRNA and mRNA results support its existence. Despite the fact that data on miRNA function and correlations with immunity and inflammation come mainly from human models, they are highly conserved among species. For instance, the high similarity between miRNA sequences between Bos taurus and Homo sapiens obtained using blastn (National Center for Biotechnology Information, Bethesda, MD) indicates a similar function in bovine (Supplemental Table S8; https://doi.org/10.3168/ jds.2016-11790). Furthermore, the degree of similarity between CCL2 mRNA and protein between bovine and human is high (blastn and blastp, Supplemental Table S9; https://doi.org/10.3168/jds.2016-11790). This is valid also for MMP12 (which activates CCL2), and the receptors CCR2 and CCR4. Thus, because CCL2 was detectable in the present study, we speculate a similarity in function in bovine compared with human. Overall, the blastn and the blastp results (Supplemental Tables S8 and S9; https://doi.org/10.3168/jds.2016-11790) support the existence of similar function in human and bovine of the many players involved in the immune cell infiltration of adipose tissue.

\section{Far-Off, Nonlactating Period Nutrition}

Far-off nutrition in TMR-based herds is normally designed to meet basic nutrition requirements (e.g., maintenance and gestation), while avoiding excessive storage of reserves that could impair the animal adaptation to the next lactation. However, in grazing systems, cows are generally dried off at a BCS too low to ensure a proper transition into lactation, thus leading to the need to fatten cows before parturition (Roche et al., 2007). Judging by the upregulation of pro-adipogenic
miRNA, also observed in previous research [miR-143, miR-378 (Jin et al., 2009, 2010)], it can be surmised that overfeeding cows in the far-off period is a suitable management practice to meet adiposity requirements at calving, with FastBCS cows still exhibiting lipogenic traits at a week prepartum (i.e., approximately $2 \mathrm{wk}$ after they were switched to different close-up feeding management). Despite this, the lack of change in expression of their common target gene, $P P A R G$, was suggestive that the pro-adipogenic effect of these miRNA might have been achieved through the regulation of other target genes (i.e., MPAK1, ERK5).

Although overfeeding thinner cows after dry-off (i.e., FastBCS) did not have long-term effects on expression of adipogenic genes, it seemed to prime the adipose tissue to retain rather than release fatty acid reserves in early lactation. This was surmised by the greater overall concentration of circulating fatty acids in SlowBCS cows compared with FastBCS cows (Roche et al., 2016, and Table 6). This hypothesis is also supported by the expression of miR-99a and miR-145 in FastBCS cows. In humans, miR-99a is negatively correlated with the concentrations of free FA within adipocytes (Kloting et al., 2009) and miR-145 regulates adipocyte lipolysis through different mechanisms (Lorente-Cebrian et al., 2014). Despite the lower BCS in FastBCS cows at $1 \mathrm{wk}$ postpartum, the lower overall expression of miR-99a and the higher expression of miR-145 in SlowBCS cows support their greater lipolysis than in FastBCS cows.

It is possible that the greater degree of mobilization in SlowBCS cows was partly regulated by infiltration of immune cells within the adipose tissue. Despite both chemokines (CCL2 and CCL5) not being affected by far-off management, signs of infiltration could be discerned in SlowBCS cows because of the greater expression of both miR-132 and miR-155, which are markers of macrophage infiltration in humans (Kloting et al., 2009 ; i.e., an overall effect for the first and prepartum for the latter). In addition, the prepartum expression of miR-126, a CCL2 inhibitor that leads to reduced infiltration of immune cells (Arner et al., 2012), was lower in the same cows.

In the present study, the expression of both TLR (TLR 4 and TLR9) was studied as a way to connect metabolism and inflammatory signals. Signaling through TLR4 in nonruminants can induce insulin resistance and lipolysis in adipocytes (Shi et al., 2006; Song et al., 2006). Thus, the dual activation of TLR4 in adipocytes by lipopolysaccharide and fatty acids represents a molecular gate that connects innate immunity with metabolism (Schaffler and Scholmerich, 2010). In the same fashion, TLR9, originally identified in nonruminants as a sensor of exogenous DNA fragments (Scharfe-Nugent et al., 2012), can also be activated by fatty acids, lead- 
ing to chronic adipose tissue inflammation and insulin resistance (Pallares et al., 2010; Nishimoto et al., 2016).

Because cows in the present experiment were clinically healthy and free from pathogen-related inflammatory events (e.g., cows passed a veterinary clinical examination), activation of TLR 4 and TLR 9 in SlowBCS cows likely was mediated by fatty acids; hence, they transmitted lipolytic signals to the tissue. The greater activation of both TLR could be surmised not only by their greater expression, but also by the greater expression of IL6 in the same cows. In fact, TLR 4 activation is known to induce IL6 expression, both in adipocytes and macrophages (Shi et al., 2006). In nonruminants, IL-6 is known to have lipolytic effects (Yang et al., 2008) at least, in part, due to its ability to enhance insulin resistance (Shoelson et al., 2007). Because miR-99a was negatively correlated with secretion of IL-6 (Kloting et al., 2009) in nonruminants, we speculate that the greater overall expression of IL 6 in SlowBCS cows might partly be attributed to infiltrating macrophages rather than adipocytes themselves. This scenario has been demonstrated in models of human obesity, as release of interleukins and other inflammatory cytokines from human adipose depots is enhanced in obesity, primarily due to the nonfat cells (Fain, 2006). However, further research is needed to localize the origin (e.g., immune cells, or nonfat cells) of IL6 expression in the tissue.

At least in cows that reached the end of lactation at a greater BCS, and were not overfed during the far-off period, these relationships underscored the importance of immunological control of lipolysis. We further speculate the existence of a positive-feedback loop between FA and immune cell infiltration. Whether the observed effects were due to nutrition management only or BCS at drying off requires further research.

\section{Close-Up Feeding}

A general outcome when overfeeding cows during the close-up period is a decrease in adipose mobilization and greater storage of surplus nutrients (Ji et al., 2012). The marked decrease in the overall concentration of circulating FA along the entire transition period, and $\mathrm{BHB}$ and cholesterol in the prepartum period, in cows fed $120 \%$ of ME requirements (Feed120) all indicate a decrease in lipid mobilization. This systemic effect was mirrored peripherally by the downregulation of lipolytic and insulin resistance signaling genes (e.g., lower IL1B, IL6R, TLR9; Lagathu et al., 2006; Yang et al., 2008; Pallares et al., 2010). Paradoxically, however, the downregulation of FASN and the pro-adipogenic miR378 and miR-143 (Jin et al., 2009, 2010), as well as $A D I P O Q$, in Feed120 cows was indicative of a reduction in the differentiation and proliferation of adipocytes in the overfeeding treatment.

The response in $A D I P O Q$ expression (e.g., lower in Feed120) was particularly interesting because, in nonruminants, the increase in its expression improves insulin sensitivity and exerts some regulation over fatty acid metabolism (Brochu-Gaudreau et al., 2010). Expression of $A D I P O Q$ also is markedly increased during ruminant adipocyte differentiation (Roh et al., 2006). Thus, lower expression of $A D I P O Q$ is a marker of reduced pre-adipocyte differentiation (Soliman et al., 2007). In vivo data also revealed a tendency for a reduction of circulating ADIPOQ during overconditioning (similar to our mRNA data; Locher et al., 2015), but the cows, opposite to the present study, also gained weight and BCS over time. In light of these seemingly paradoxical responses, questions arise on the use of the excess energy by adipose. For example, because adipose did not seem to accrete additional triglycerides and BCS did not change in the week before parturition (Roche et al., 2016), the additional intake could have been entirely partitioned toward meeting the requirements for gestation. In fact, cows did not experience an increase in adiposity, but their BW increased before parturition (Roche et al., 2016).

Despite the apparent absence of new fat deposition, the adipose tissue of overfed cows seemed to respond similar to what is observed in fat depots from obese individuals in the sense that infiltration of immune cells appeared to be stimulated by the excess feeding. The overall upregulation of the chemokine gene, CCL2, coupled with upregulation of miR-132 and miR-155, led us to speculate an increase in infiltration of immune cells (Kloting et al., 2009). Such a response normally increases insulin resistance and lipid mobilization to avoid excess storage in adipocytes and associated detrimental effects (Olefsky and Glass, 2010).

As lipolytic and insulin resistance signals are suppressed (IL1B, IL6R, TLR9) in Feed120 cows, the tentative onset of an inflammatory cascade could be a response to the need for mobilization to meet lactation requirements postpartum; however, it could also be related to the need to establish new reserves. This idea is supported by recent data demonstrating that adipocyte inflammation is an important component for a healthy expansion and remodeling of the adipose tissue (Asterholm et al., 2014). In either scenario, the apparent immune-related tendency to kick start an inflammatory response to modulate metabolism could be a reaction to what has been previously described as a "lazy" phenotype in cows overfed prepartum (Vailati Riboni et al., 2016). This concept shares strong similarities with the well-known calcium metabolism and nutrition of 
the dry cow, as overfeeding calcium before parturition will increase the risk of metabolic failures (e.g., milk fever) by dampening the physiological mechanisms behind calcium homeostasis (Horst et al., 1997).

Contrary to overfeeding, a strong feed restriction (Feed65) elicited a clear outcome. The phenotypic data from this study indicated that such severe restriction during the pre-calving period increases the risk of disease in early lactation and reduces milk production (Roche et al., 2016). These cows experienced an excessive degree of mobilization of tissue reserves prepartum (Table 6), together with a reduction in BCS, but without a loss of BW (Roche et al., 2016).

The present transcriptome data point to a negativefeedback salvage mechanism (i.e., due to the excess mobilization prepartum, cows experience an even greater loss of reserves in the postpartum). Despite the contention that evolutionary programming of animal physiology is pointed toward the offspring rather than the mother (Bauman and Currie, 1980), the downregulation of a possible immune infiltration signal (CCL2) and lipolytic signal (IL6) postpartum, and the upregulation of the pro-adipogenic miR-143 (at least prepartum) in Feed65 cows could represent an attempt by the fat depots of the cow to control and maintain its reserves, as under extreme circumstances (e.g., malnourishment) the physiological priority can come back to the mother (Bauman and Currie, 1980).

Considering the entire set of mRNA and miRNA analyzed, and contrary to expectations, a slight restriction (Feed90) during the transition period was the main driver of changes in expression of most target genes. These changes, however, did not create an extreme phenotype, and rather seemed to be part of the natural physiological adaptation to lactation. The overall upregulation of immune lipolytic signaling (e.g., IL1B, TLR 4, TLR9), combined with the lowest expression of miR-155 and the absence of a clear change in chemokine expression (both CCL2 and CCL5), underscored that the fat depots of these cows did not rely on the action of immune cells to regulate and induce changes in metabolism. Furthermore, the marked upregulation prepartum in Feed90 of pro-adipogenic genes (e.g., PPARG, FASN, and ADIPOQ) indicated an equilibrating mechanism to balance lipolytic and anti-lipolytic signals to prime the mobilization machinery in light of the imminent parturition. Once this balancing mechanism was complete (PPARG, FASN, and $A D I P O Q$ expression decreased after parturition), the lipolytic signaling and insulin resistance mechanisms are already established and can fully act on adipocyte metabolism (i.e., IL6, IL6R, TLR 4, TLR9, and $T N F$ all had a higher expression postpartum in Feed90 cows).
Together, these changes led to a numerically greater, but nonsignificant, level of circulating FA in early lactation (Table 6). As indicated by the higher expression postpartum of miR-126, a direct inhibitor of chemokine CCL2 (Arner et al., 2012), these changes did not seem to encompass an infiltration of immune cells. We speculate that the involvement of the innate immune system in regulating adipocyte metabolism may only occur in extreme nutritional situations (e.g., Feed65, Feed120), similar to the obesity scenario in humans, or in clinical scenarios [e.g., displaced abomasum (Contreras et al., 2015)], in which most of the relationships among immunity and metabolism have already been well studied.

\section{Possible Interaction of Far-Off and Close-Up Nutritional Strategies}

No interactions among far-off management and closeup feeding level were detected for production and health outcomes as presented in the main manuscript concerning this experiment (Roche et al., 2016). However, at a molecular level (adipocyte transcriptome), distinct and similar changes were caused by their interaction in SlowBCS-Feed120 and FastBCS-Feed65 cows. Both groups experienced a state of low lipolytic signaling and higher insulin sensitivity (low $I L 1 B, T N F$ ) during the entire transition period. Such a physiological state would have been supported by the higher expression of miR-99a, which in nonruminants is inversely correlated with IL-6 secretion and FA concentration (Kloting et al., 2009), miR-221, which is inversely correlated with TNF- $\alpha$ secretion (Chou et al., 2013), and miR-126, which is a CCL2 inhibitor (Arner et al., 2012).

Although adipose tissue of SlowBCS-Feed120 and FastBCS-Feed65 cows appears not to have been primed to mobilize its reserves, at least from the genes studied, it also did not seem to signal an increase in TAG storage because the expression of FASN and RXRA was markedly lower compared with the other experimental groups. To further complicate this scenario of an apparent metabolic "stasis," contradictory responses were detected. Both miR-155 and miR-145 were upregulated in SlowBCS-Feed120 and FastBCS-Feed65, suggesting greater immune cell infiltration (Kloting et al., 2009) and lipolytic activity (Lorente-Cebrian et al., 2014), whereas miR-103 was also upregulated, possibly increasing insulin sensitivity (Trajkovski et al., 2011) and stimulating pro-adipogenic signaling (Romao et al., 2011, 2014). Thus, the metabolic effect of the interactions detected remains unclear and is further complicated by the lack of interaction at the phenotype level. Further research is needed to better characterize the physiology of the relationships among far-off and close-up nutrition. 


\section{CONCLUSIONS}

The current results support the hypothesis that bovine adipose tissue possesses a homeorhetic mechanism for the adaptation to lactation, driven, in part, by inflammatory changes and, we speculate, in a cross-talk with the innate immune system. This mechanism appears to be modulated by peripartal nutrition. Overfeeding animals in the far-off period to achieve optimal calving BCS (FastBCS) reduced the propensity to mobilize adipose depots after parturition; however, animals that were managed in late lactation to dry-off at optimal calving BCS (SlowBCS) seemed more primed to lose BCS in early lactation. Concerning close-up nutrition, what seems to be a natural progression of self-driven inflammatory events in slightly underfed cows (Feed90) can be modulated both by underfeeding (Feed65) or overfeeding (Feed120), which we speculate caused the recruitment of the innate immune system to help modulate adipocyte metabolism. In light of the present results, to obtain a favorable transition to lactation, at least in grazing systems, dairy cows should be managed to achieve an optimal calving BCS at close-up, either by overfeeding thinner cows or control-feeding those already dried-off at target BCS, as neither strategy (FastBCS, SlowBCS), despite their different outcomes, interferes in the physiological adaptation. Subsequently, in the close-up period, BCS should be managed by applying a slight feed restriction closer to calving.

\section{ACKNOWLEDGMENTS}

The authors thank Bruce Sugar (Farm Manager, Lye Farm, DairyNZ) and his capable team, as well as Stu Morgan, Kate Watkins, Ben Fisher, Kelly Collier, and Chris Roach (DairyNZ) for technical support, and Barbara Kuhn-Sherlock (DairyNZ) for statistical analysis and advice. This research was supported by New Zealand dairy farmers through DairyNZ Inc. (RD1403) and the New Zealand Ministry of Business, Innovation, and Employment (DRCX1201).

\section{REFERENCES}

Adamczak, M., and A. Wiecek. 2013. The adipose tissue as an endocrine organ. Semin. Nephrol. 33:2-13.

Akbar, H., T. M. Grala, M. V. Riboni, F. C. Cardoso, G. Verkerk, J. McGowan, K. Macdonald, J. Webster, K. Schutz, S. Meier, L. Matthews, J. R. Roche, and J. J. Loor. 2015. Body condition score at calving affects systemic and hepatic transcriptome indicators of inflammation and nutrient metabolism in grazing dairy cows. J. Dairy Sci. 98:1019-1032.

Akter, S. H., S. Haussler, D. Germeroth, D. von Soosten, S. Danicke, K. H. Sudekum, and H. Sauerwein. 2012. Immunohistochemical characterization of phagocytic immune cell infiltration into different adipose tissue depots of dairy cows during early lactation. J. Dairy Sci. 95:3032-3044.
Arner, E., N. Mejhert, A. Kulyte, P. J. Balwierz, M. Pachkov, M. Cormont, S. Lorente-Cebrian, A. Ehrlund, J. Laurencikiene, P. Heden, K. Dahlman-Wright, J. F. Tanti, Y. Hayashizaki, M. Ryden, I. Dahlman, E. van Nimwegen, C. O. Daub, and P. Arner. 2012. Adipose tissue MicroRNAs as regulators of CCL2 production in human obesity. Diabetes 61:1986-1993.

Arner, P., and A. Kulyte. 2015. MicroRNA regulatory networks in human adipose tissue and obesity. Nat. Rev. Endocrinol. 11:276-288.

Asterholm, I. W., C. Tao, T. S. Morley, Q. A. Wang, F. Delgado-Lopez, Z. V. Wang, and P. E. Scherer. 2014. Adipocyte inflammation is essential for healthy adipose tissue expansion and remodeling. Cell Metab. 20:103-118.

Bauman, D. E., and W. B. Currie. 1980. Partitioning of nutrients during pregnancy and lactation: A review of mechanisms involving homeostasis and homeorhesis. J. Dairy Sci. 63:1514-1529.

Boutflour, R. B. 1928. Limiting factors in the feeding and management of milk cows. Report of Proceedings of 8th World's Dairy Congress, London, UK.

Brochu-Gaudreau, K., C. Rehfeldt, R. Blouin, V. Bordignon, B. D. Murphy, and M. F. Palin. 2010. Adiponectin action from head to toe. Endocrine 37:11-32.

Chou, W. W., Y. C. Liao, S. C. Chuang, S. N. Wang, and S. H. Juo. 2013. Decreased microRNA-221 is associated with high levels of TNF-alpha in human adipose tissue-derived mesenchymal stem cells from obese woman. Cell. Physiol. Biochem. 32:127-137.

Contreras, G. A., E. Kabara, J. Brester, L. Neuder, and M. Kiupel. 2015. Macrophage infiltration in the omental and subcutaneous adipose tissues of dairy cows with displaced abomasum. J. Dairy Sci. 98:6176-6187.

Dann, H. M., N. B. Litherland, J. P. Underwood, M. Bionaz, A. D'Angelo, J. W. McFadden, and J. K. Drackley. 2006. Diets during far-off and close-up dry periods affect periparturient metabolism and lactation in multiparous cows. J. Dairy Sci. 89:3563-3577.

Dodson, M. V., M. Du, S. Wang, W. G. Bergen, M. FernyhoughCulver, U. Basu, S. P. Poulos, and G. J. Hausman. 2014. Adipose depots differ in cellularity, adipokines produced, gene expression, and cell systems. Adipocyte 3:236-241.

Esau, C., X. Kang, E. Peralta, E. Hanson, E. G. Marcusson, L. V. Ravichandran, Y. Sun, S. Koo, R. J. Perera, R. Jain, N. M. Dean, S. M. Freier, C. F. Bennett, B. Lollo, and R. Griffey. 2004. MicroRNA-143 regulates adipocyte differentiation. J. Biol. Chem. 279:52361-52365.

Estep, M., D. Armistead, N. Hossain, H. Elarainy, Z. Goodman, A. Baranova, V. Chandhoke, and Z. M. Younossi. 2010. Differential expression of miRNAs in the visceral adipose tissue of patients with non-alcoholic fatty liver disease. Aliment. Pharmacol. Ther. 32:487-497

Fain, J. N. 2006. Release of interleukins and other inflammatory cytokines by human adipose tissue is enhanced in obesity and primar ily due to the nonfat cells. Vitam. Horm. 74:443-477.

Farney, J. K., L. K. Mamedova, J. F. Coetzee, B. KuKanich, L. M. Sordillo, S. K. Stoakes, J. E. Minton, L. C. Hollis, and B. J. Bradford. 2013. Anti-inflammatory salicylate treatment alters the metabolic adaptations to lactation in dairy cattle. Am. J. Physiol. Regul. Integr. Comp. Physiol. 305:R110-R117.

Gerin, I., G. T. Bommer, C. S. McCoin, K. M. Sousa, V. Krishnan and O. A. MacDougald. 2010. Roles for miRNA-378/378* in adipocyte gene expression and lipogenesis. Am. J. Physiol. Endocrinol. Metab. 299:E198-E206.

Grala, T. M., J. R. Roche, C. V. Phyn, A. G. Rius, R. H. Boyle, R. G. Snell, and J. K. Kay. 2013. Expression of key lipid metabolism genes in adipose tissue is not altered by once-daily milking during a feed restriction of grazing dairy cows. J. Dairy Sci. 96:7753-7764.

Grant, R. W., and V. D. Dixit. 2015. Adipose tissue as an immunological organ. Obesity (Silver Spring) 23:512-518.

Graugnard, D. E., K. M. Moyes, E. Trevisi, M. J. Khan, D. Keisler, J. K. Drackley, G. Bertoni, and J. J. Loor. 2013. Liver lipid content and inflammometabolic indices in peripartal dairy cows are altered in response to prepartal energy intake and postpartal intramammary inflammatory challenge. J. Dairy Sci. 96:918-935. 
Haussler, S., C. Sacre, K. Friedauer, S. Danicke, and H. Sauerwein. 2015. Short communication: localization and expression of monocyte chemoattractant protein-1 in different subcutaneous and visceral adipose tissues of early-lactating dairy cows. J. Dairy Sci. 98:6278-6283.

Holtenius, K., S. Agenas, C. Delavaud, and Y. Chilliard. 2003. Effects of feeding intensity during the dry period. 2. Metabolic and hormonal responses. J. Dairy Sci. 86:883-891.

Horst, R. L., J. P. Goff, T. A. Reinhardt, and D. R. Buxton. 1997. Strategies for preventing milk fever in dairy cattle. J. Dairy Sci. 80:1269-1280.

Janovick, N. A., Y. R. Boisclair, and J. K. Drackley. 2011. Prepartum dietary energy intake affects metabolism and health during the periparturient period in primiparous and multiparous Holstein cows. J. Dairy Sci. 94:1385-1400.

Ji, P., J. K. Drackley, M. J. Khan, and J. J. Loor. 2014. Overfeeding energy upregulates peroxisome proliferator-activated receptor (PPAR)gamma-controlled adipogenic and lipolytic gene networks but does not affect proinflammatory markers in visceral and subcutaneous adipose depots of Holstein cows. J. Dairy Sci. 97:34313440.

Ji, P., J. S. Osorio, J. K. Drackley, and J. J. Loor. 2012. Overfeeding a moderate energy diet prepartum does not impair bovine subcutaneous adipose tissue insulin signal transduction and induces marked changes in peripartal gene network expression. J. Dairy Sci. 95:4333-4351.

Jin, W., M. V. Dodson, S. S. Moore, J. A. Basarab, and L. L. Guan. 2010. Characterization of microRNA expression in bovine adipose tissues: A potential regulatory mechanism of subcutaneous adipose tissue development. BMC Mol. Biol. 11:29.

Jin, W., J. R. Grant, P. Stothard, S. S. Moore, and L. L. Guan. 2009. Characterization of bovine miRNAs by sequencing and bioinformatics analysis. BMC Mol. Biol. 10:90.

John, E., A. Wienecke-Baldacchino, M. Liivrand, M. Heinaniemi, C. Carlberg, and L. Sinkkonen. 2012. Dataset integration identifies transcriptional regulation of microRNA genes by PPARgamma in differentiating mouse 3T3-L1 adipocytes. Nucleic Acids Res. 40:4446-4460.

Kajimoto, K., H. Naraba, and N. Iwai. 2006. MicroRNA and 3T3-L1 pre-adipocyte differentiation. RNA 12:1626-1632.

Khan, M. J., C. B. Jacometo, D. E. Graugnard, M. N. Correa, E. Schmitt, F. Cardoso, and J. J. Loor. 2014. Overfeeding dairy cattle during late-pregnancy alters hepatic PPARalpha-regulated pathways including hepatokines: Impact on metabolism and peripheral insulin sensitivity. Gene Regul. Syst. Bio. 8:97-111.

Kloting, N., S. Berthold, P. Kovacs, M. R. Schon, M. Fasshauer, K. Ruschke, M. Stumvoll, and M. Bluher. 2009. MicroRNA expression in human omental and subcutaneous adipose tissue. PLoS One 4:e4699.

Lagathu, C., L. Yvan-Charvet, J. P. Bastard, M. Maachi, A. Quignard-Boulange, J. Capeau, and M. Caron. 2006. Long-term treatment with interleukin-1beta induces insulin resistance in murine and human adipocytes. Diabetologia 49:2162-2173.

Li, H., Z. Zhang, X. Zhou, Z. Wang, G. Wang, and Z. Han. 2011. Effects of microRNA-143 in the differentiation and proliferation of bovine intramuscular preadipocytes. Mol. Biol. Rep. 38:4273-4280.

Liu, S. Y., Y. Y. Zhang, Y. Gao, L. J. Zhang, H. Y. Chen, Q. Zhou, M. L. Chai, Q. Y. Li, H. Jiang, B. Yuan, L. S. Dai, and J. B. Zhang. 2015. MiR-378 plays an important role in the differentiation of bovine preadipocytes. Cell. Physiol. Biochem. 36:1552-1562.

Locher, L., S. Haussler, L. Laubenthal, S. P. Singh, J. Winkler, A. Kinoshita, A. Kenez, J. Rehage, K. Huber, H. Sauerwein, and S. Danicke. 2015. Effect of increasing body condition on key regulators of fat metabolism in subcutaneous adipose tissue depot and circulation of nonlactating dairy cows. J. Dairy Sci. 98:1057-1068.

Lorente-Cebrian, S., N. Mejhert, A. Kulyte, J. Laurencikiene, G. Astrom, P. Heden, M. Ryden, and P. Arner. 2014. MicroRNAs regulate human adipocyte lipolysis: Effects of miR-145 are linked to TNF-alpha. PLoS One 9:e86800.

McGown, C.. A. Birerdinc, and Z. M. Younossi. 2014. Adipose tissue as an endocrine organ. Clin. Liver Dis. 18:41-58.
McNamara, J. P. 1991. Regulation of adipose tissue metabolism in support of lactation. J. Dairy Sci. 74:706-719.

McNamara, J. P. 1997. Adipose tissue metabolism during lactation: Where do we go from here? Proc. Nutr. Soc. 56(1A):149-167.

Moisá, S. J., D. W. Shike, L. Shoup, and J. J. Loor. 2016. Maternal plane of nutrition during late-gestation and weaning age alter steer calf longissimus muscle adipogenic microRNA and target gene expression. Lipids 51:123-138.

Mukesh, M., M. Bionaz, D. E. Graugnard, J. K. Drackley, and J. J. Loor. 2009. Adipose tissue depots of Holstein cows are immune responsive: Inflammatory gene expression in vitro. Domest. Anim. Endocrinol. 38:168-178.

Musi, N., and R. Guardado-Mendoza. 2014. Adipose tissue as an endocrine organ. Pages 229-237 in Cellular Endocrinology in Health and Disease. A. Ulloa-Aguirre and P. Michael Conn, ed. Academic Press, Boston, MA.

Nishimoto, S., D. Fukuda, Y. Higashikuni, K. Tanaka, Y. Hirata, C. Murata, J. R. Kim-Kaneyama, F. Sato, M. Bando, S. Yagi, T. Soeki, T. Hayashi, I. Imoto, H. Sakaue, M. Shimabukuro, and M. Sata. 2016. Obesity-induced DNA released from adipocytes stimulates chronic adipose tissue inflammation and insulin resistance. Sci. Adv. 2:e1501332

Olefsky, J. M., and C. K. Glass. 2010. Macrophages, inflammation, and insulin resistance. Annu. Rev. Physiol. 72:219-246.

Pallares, V., A. Castell-Auvi, L. Cedo, M. Pinent, A. Ardevol, and M. Blay. 2010. A paracrine loop between adipocytes and macrophages in adipose tissue: An in vitro model to study obesity-induced inflammation. J. Nutrigenet. Nutrigenomics 3:96.

Pires, J. A. A., C. Delavaud, Y. Faulconnier, D. Pomies, and Y. Chilliard. 2013. Effects of body condition score at calving on indicators of fat and protein mobilization of periparturient Holstein-Friesian cows. J. Dairy Sci. 96:6423-6439.

Randall, L. V., M. J. Green, M. G. Chagunda, C. Mason, S. C. Archer, L. E. Green, and J. N. Huxley. 2015. Low body condition predisposes cattle to lameness: An 8-year study of one dairy herd. J. Dairy Sci. 98:3766-3777.

Roche, J. R., D. P. Berry, J. M. Lee, K. A. Macdonald, and R. C. Boston. 2007. Describing the body condition score change between successive calvings: A novel strategy generalizable to diverse cohorts. J. Dairy Sci. 90:4378-4396.

Roche, J. R., P. G. Dillon, C. R. Stockdale, L. H. Baumgard, and M. J. VanBaale. 2004. Relationships among international body condition scoring systems. J. Dairy Sci. 87:3076-3079.

Roche, J. R., N. C. Friggens, J. K. Kay, M. W. Fisher, K. J. Stafford, and D. P. Berry. 2009. Invited review: Body condition score and its association with dairy cow productivity, health, and welfare. J. Dairy Sci. 92:5769-5801.

Roche, J. R., A. Heiser, M. D. Mitchell, M. A. Crookenden, C. G. Walker, J. K. Kay, M. Vailati Riboni, J. J. Loor, and S. Meier. 2016. Effects of far-off and close-up dry matter intake on production and metabolic health parameters in pasture-based transition dairy cows. J. Dairy Sci. https://doi.org/10.3168/jds.2016-11591.

Roche, J. R., E. S. Kolver, and J. K. Kay. 2005. Influence of precalving feed allowance on periparturient metabolic and hormonal responses and milk production in grazing dairy cows. J. Dairy Sci. 88:677-689.

Roh, S.-G., D. Hishikawa, Y.-H. Hong, and S. Sasaki. 2006. Control of adipogenesis in ruminants. Anim. Sci. 77:472-477.

Romao, J. M., W. Jin, M. V. Dodson, G. J. Hausman, S. S. Moore, and L. L. Guan. 2011. MicroRNA regulation in mammalian adipogenesis. Exp. Biol. Med. (Maywood) 236:997-1004.

Romao, J. M., W. Jin, M. He, T. McAllister, and L. Guan le. 2014. MicroRNAs in bovine adipogenesis: Genomic context, expression and function. BMC Genomics 15:137.

Rukkwamsuk, T., T. Wensing, and M. J. Geelen. 1999. Effect of overfeeding during the dry period on the rate of esterification in adipose tissue of dairy cows during the periparturient period. J. Dairy Sci. 82:1164-1169.

Sacco, J., and K. Adeli. 2012. MicroRNAs: Emerging roles in lipid and lipoprotein metabolism. Curr. Opin. Lipidol. 23:220-225. 
Schaffler, A., and J. Scholmerich. 2010. Innate immunity and adipose tissue biology. Trends Immunol. 31:228-235.

Scharfe-Nugent, A., S. C. Corr, S. B. Carpenter, L. Keogh, B. Doyle, C. Martin, K. A. Fitzgerald, S. Daly, J. J. O'Leary, and L. A. J. O'Neill. 2012. TLR9 provokes inflammation in response to fetal DNA: Mechanism for fetal loss in preterm birth and preeclampsia. J. Immunol. 188:5706-5712.

Shahzad, K., M. Bionaz, E. Trevisi, G. Bertoni, S. L. Rodriguez-Zas, and J. J. Loor. 2014. Integrative analyses of hepatic differentially expressed genes and blood biomarkers during the peripartal period between dairy cows overfed or restricted-fed energy prepartum. PLoS One 9:e99757.

Shi, H., M. V. Kokoeva, K. Inouye, I. Tzameli, H. Yin, and J. S. Flier. 2006. TLR4 links innate immunity and fatty acid-induced insulin resistance. J. Clin. Invest. 116:3015-3025.

Shoelson, S. E., L. Herrero, and A. Naaz. 2007. Obesity, inflammation, and insulin resistance. Gastroenterology 132:2169-2180.

Soliman, M., K. Kimura, M. Ahmed, D. Yamaji, Y. Matsushita, Y. Okamatsu-Ogura, K. Makondo, and M. Saito. 2007. Inverse regulation of leptin mRNA expression by short- and long-chain fatty acids in cultured bovine adipocytes. Domest. Anim. Endocrinol. 33:400-409.

Song, M. J., K. H. Kim, J. M. Yoon, and J. B. Kim. 2006. Activation of Toll-like receptor 4 is associated with insulin resistance in adipocytes. Biochem. Biophys. Res. Commun. 346:739-745.

Strum, J. C., J. H. Johnson, J. Ward, H. B. Xie, J. Feild, A. Hester, A. Alford, and K. M. Waters. 2009. MicroRNA 132 regulates nutritional stress-induced chemokine production through repression of SirT1. Mol. Endocrinol. 23:1876-1884.

Trajkovski, M., J. Hausser, J. Soutschek, B. Bhat, A. Akin, M. Zavolan, M. H. Heim, and M. Stoffel. 2011. MicroRNAs 103 and 107 regulate insulin sensitivity. Nature 474:649-653.
Vailati Riboni, M., M. Kanwal, O. Bulgari, S. Meier, N. V. Priest, C. R. Burke, J. K. Kay, S. McDougall, M. D. Mitchell, C. G. Walker, M. Crookenden, A. Heiser, J. R. Roche, and J. J. Loor. 2016. Body condition score and plane of nutrition prepartum affect adipose tissue transcriptome regulators of metabolism and inflammation in grazing dairy cows during the transition period. J. Dairy Sci. 99:758-770.

Vailati Riboni, M., S. Meier, N. V. Priest, C. R. Burke, J. K. Kay, S. McDougall, M. D. Mitchell, C. G. Walker, M. Crookenden, A. Heiser, J. R. Roche, and J. J. Loor. 2015. Adipose and liver gene expression profiles in response to treatment with a nonsteroidal antiinflammatory drug after calving in grazing dairy cows. J. Dairy Sci. 98:3079-3085.

von Soosten, D., U. Meyer, E. M. Weber, J. Rehage, G. Flachowsky, and S. Danicke. 2011. Effect of trans-10, cis-12 conjugated linoleic acid on performance, adipose depot weights, and liver weight in early-lactation dairy cows. J. Dairy Sci. 94:2859-2870.

Waltner, S. S., J. P. McNamara, and J. K. Hillers. 1993. Relationships of body condition score to production variables in high producing Holstein dairy cattle. J. Dairy Sci. 76:3410-3419.

Xie, H., B. Lim, and H. F. Lodish. 2009. MicroRNAs induced during adipogenesis that accelerate fat cell development are downregulated in obesity. Diabetes 58:1050-1057.

Xu, G., C. Ji, C. Shi, H. Fu, L. Zhu, L. Zhu, L. Xu, L. Chen, Y. Feng, Y. Zhao, and X. Guo. 2013. Modulation of hsa-miR-26b levels following adipokine stimulation. Mol. Biol. Rep. 40:3577-3582.

Yang, Y., D. Ju, M. Zhang, and G. Yang. 2008. Interleukin-6 stimulates lipolysis in porcine adipocytes. Endocrine 33:261-269. 